\title{
The Constitutional Right to Healthcare and Medical Care for Students in Schools: Chosen Aspects

\author{
Lyaysan Renatovna Mustafina
}

\author{
Assistant, \\ Department of Constitutional and Administrative Law, \\ Kazan Federal University
}

\section{Gulnara Mullanurovna Khamitova}

\author{
Senior Lecturer, \\ Medical Law and Medicine History, \\ Department of Biomedicine, \\ Kazan State Medical University
}

Doi: $10.36941 /$ jesr-2019-0007

\begin{abstract}
The problem of legislative entrancement and protection of students' rights in the sphere of healthcare is one of the most pressing. "Health is a state of complete physical, mental and social wellbeing; it is not a mere absence of ailments or physical defects". The Russian Federation students often face declarative attitude in medical practice, he is often ignored, despite having rights (property or personal) and freedoms of accessing medical assistance. In order to introduce quality changes to the system of students' rights protection in Russia, this problem requires a complex solution. The right to healthcare and medical assistance is entrenched in the domestic legislation, foremost in the Russian Federation Constitution. The right to free medical care in compliance with the program of the state-guaranteed free medical assistance, as well as paid medical service and other services, is entrenched in Article 41. Along with it no less relevant and almost undeveloped is a problem of defining the legal status of the students. How do we define and protect the rights and freedoms of them as a part of the Russian Federation entrenched in the Russian Federation Constitution accurately? In developed countries approaches to forming a legal relationship of the medical organizations with the student's need for medical care changed significantly in the past years. Many world countries, starting from the XX 90 th, carry out purposeful introducing the general principles of the students' rights, as well as other people's legal status entrenchment into their legislation, pay considerable attention to these rights' implementation mechanisms. Thus, the problem of students' legal status, which complexity is predetermined by the law specifics, is one of the most difficultly resolved theoretical and practical issues in the sphere of medical-legal relationship. The present article is devoted to the analysis of specific aspects of this problem, authors offer a new approached to its resolution.
\end{abstract}

Keywords: Health Protection, Medical Care, students, Attending Physician, Denial of Medical Attention, Legal Status

\section{Introduction}

Public health care is one of the most relevant activities of any state as the health of citizens is also the welfare of the state. In this regard, the last decades are characterized by the fact that in the developed foreign countries the attitude towards the citizen in need of medical care was changed significantly. 
For a long time, the problem of ensuring and protecting the citizen health care rights in the current legislation began to draw steadily increasing the attention of researchers and legislators and in our country. In recent years in the Russian Federation, high legislative activity in the sphere of legal regulation of protecting public health is noted; multiple works devoted to the students rights were published.

Article 41 of the Russian Federation Constitution guaranteed citizens such right as the right to health and medical care, the right which is carried out at the expense of the government budget, insurance premiums and other monetary receipts (Gutteridge, 1947). Besides, there is a Federal law "About Bases of Protection of the Public Health in the Russian Federation" as of 21.11.2011 in which all aspects concerning health care and its maintenance are lit and entrenched (Criminal Code of the Russian Federation Article 124, 2017). Though some lines in the above-mentioned federal law and in the Criminal Code of the Russian Federation are devoted to medical care denial, all the same, it remains difficult to understand in what cases the doctor or the medical organization has the right to deny health care. The current problem, on one hand, is little discussed, and on the other hand, is vital and relevant. It will be a question of protection and implementation of the students' rights when rendering medical care, as well as a matter of a legal base research and the nature of a possibility of medical attendance denial owing to some objective reasons and as well as about improving the legislation to benefit both the doctor, and the students.

\section{Methods}

General scientific methods were applied throughout the current research: analysis method, system method, comparison method, generalization method.

At the heart of the research, there is a method of analysis covering the existing Russian legislation and law-enforcement practice and the existing European (world) standards for legal unification (Dale, 1977). Methods of legal modeling and forecasting allow defining the need for implementing amendments to the existing Russian regulations as well as correcting the court practice (Davies, 2016). These methods of modeling and forecasting allowed to predict the consequences of introducing such changes and adjustments in a sufficient degree as well as reveal, how, finally, the Russian law-enforcement practice will be brought closer to the available European (world) standards (Demieva \& Arslanov, 2016). The proper sociological method enabled assessing social problems from a legal position, from a position of the legislator and the law enforcement official (Ethical Code of the Russian Doctor; 1994). The comparative and legal analysis research method was used, allowing understanding and comparing the Russian and European (world) legal standards (Medical care denial for a good reason, 2017). Use of various methods allowed to formulate the main theoretical conclusions and enabled us to propose changes to the explored sphere of public relations (Mental health: strengthening our response, 2018).

\section{Results and Discussion}

Article 11 of the Federal law "About Bases of Protection of the Public Health in the Russian Federation" as of 21.11.2011 N 323-FZ ("Inadmissibility of health care denial: 1 . Health care denial according to the program of the state guarantees free medical care to citizens and collecting payment for rendering health care services by the medical organization and students of such medical organizations are prohibited; 2 . Medical care in the emergency form is rendered by the medical organization and the student to the citizen urgently and free of charge. The medical attention denial is prohibited; 3 . The medical organizations and students bear responsibility according to the legislation of the Russian Federation for violation of the requirements provided by Parts 1 and 2 of the present article") (Olmos, 2007), would seem to gives the exact answer to the question "Whether We Will Allow Health care denial?" - "Health care denial according to the program of the state guarantees free medical care to citizens and collecting payment for rendering health care services by the medical organization are prohibited". At the same time, there is Article 70 of the same statutory act devoted to the rights and duties of the attending physician in which the right of the attending physician for denying attendance to students. In this article of the Federal Law 
it is not specified in which case the attending physician has the right to deny the students attendance and treatment (not at the cost of damage to the students' health, of course) in spite of the fact that the matter was brought up in the Ethical code of the Russian Doctor. It was specified in this Code that the doctor can refuse to work with the students, having transferred him to another specialist due to the following reasons:

- if the medical specialist feels insufficiently competent, has no necessary technical means for rendering the help of a due type;

- this type of medical care contradicts the moral principles of the doctor;

- the doctor is unable to establish therapeutic cooperation with the students (Russian Federation Constitution, 1993).

The listed provisions are not entrenched at the legislative level, they are not obligatory. At the same time, in our opinion, there is a strong reason to add them to the legislation for their full use as at least two or three of these provisions can significantly influence the student's treatment and rendering high-quality medical services. I will not be an exaggeration to say that sometimes the students or his representative owing to the objective and subjective reasons is unable to understand the existing features of diagnostics and treatment of some types of diseases, in this case, treatment denial corresponding to the above provisions will urge the students to address the experts offered by the doctor. The experts will be able to provide medical care to the necessary extent.

The problem is aggravated by the student's autonomy according to which, the doctor has no right to make decisions without the consent of the students, which means that the students act as the competent consumer of medical services and demands comprehensive information on the disease, treatment methods, and rehabilitation.

In Article 11 of the Federal law "About Bases of Protection of the Public Health in the Russian Federation" as of 21.11.2011 N 323-FZ (Criminal Code of the Russian Federation Article 124, 2017), as mentioned above, there is a provision on inadmissibility of denying them medical care by the medical organization, whereas in Article 70 we can see that the attending physician can refuse to work with the students in certain cases as stipulated by the law which makes the law contradictory and susceptible to misinterpretation by legally ignorant people. Not everyone has a legal education, at the same time all citizens deserve accurate and legible laws.

Problem solution may lie in terminology: the concept "attending physician" does not include the concept "student". Let us take a closer look at the definition. The Federal law states: "the student is the natural person who has the education and study in the schools...". It means that the term "attending physician" is included in the concept "student" as "... the attending physician is a doctor to whom duties on rendering medical care to the students during observation and treatment ... are assigned". The doctor is the person who received medical education and is carrying out the medical activity; no contradictions are observed here.

So how is it possible that the rights and freedoms of the student as a citizen of the Russian Federation, ensured first of all by the Russian Federation Constitution are violated in that case? They are not, because the Federal Law "About Bases of Protection of the Public Health in the Russian Federation" as of 21.11.2011 is designed, as well as standard and legal documents, to protect the rights and freedoms of the person and citizen as the least protected party of legal relationship. Realization of the student's rights for health care is legislatively entrenched, yet the legal status of students and the mechanism of implementation of their rights at the same time has often uncertain character and it is not observed in practice (Siems \& Mac Síthigh, 2012; Marques et al., 2017; Pakdel \& Talebbeydokhti, 2018).

\section{Summary}

On the basis of the above stated, we come to a conclusion that it is necessary to clarify the Article 11 of the Federal Law as of 21.11.2011 N 323-FZ "About Bases of Protection of the Public Health in the Russian Federation" [3], namely - to change its contents. Authors offer the following formulation: "Health care denial according to the program of the state guarantees of free medical care rendering to citizens and collection of a payment for such rendering by the medical 
organization participating in implementation of this program, and students of such medical organization is prohibited, the exception is made by the cases specified in Article 70 of the Federal law as of 21.11.2011 N 323-FZ "About Bases of Protection of the Public Health in the Russian Federation" (Criminal Code of the Russian Federation Article 124, 2017).

Authors find it possible to complement the Article 70 of the Federal law as of $21.11 .2011 \mathrm{~N}$ 323-FZ "About Bases of Protection of the Public Health in the Russian Federation" with the provisions reflected in the Article 7 of the Ethical Code of the Russian Doctor approved by the 4th Conference of Association of Doctors in Russia in November, 1994, that the doctor can refuse to attend to the students, should he provide a replacement specialist and due to the following reasons:

- if the doctor feels insufficiently competent, has no necessary technical means for rendering the help of a due type;

- this type of medical care contradicts the moral principles of the doctor;

- the doctor is unable to establish therapeutic cooperation with the students (Olmos, 2007).

At the same time, the rights of the students will not be violated at all, besides, the Russian Federation Constitution and the Criminal Code of the Russian Federation still stand on their guard. In the Article 124 of the Criminal code of the Russian Federation it is specified that the person assigned with the obligations will be persecuted by law in case they fail to provide help and if mild or heavy health damage to the students' health is caused by negligence, or if the inaction leads to students death (Siems \& Mac Síthigh, 2012; Boroomand et al., 2016; Radhy, 2019).). This norm is a reliable guarantee of the students' rights protection against the unscrupulous medical organizations and students.

Introducing the changes offered above into the Federal law as of 21.11.2011 N 323-FZ "About Bases of Protection of the Public Health in the Russian Federation" will undoubtedly have a positive effect on the legal status of the medical organization and the student and on the legal status of the students and his representatives. It is obvious that in this relationship inevitably there is also a human factor and both parties can fall victim to a misunderstanding that may finally affect the treatment result drastically. When the doctor experiences difficulties working with the students, for example, insufficient mutual understanding, conveying information, he will be able to withdraw from rendering further treatment and to transfer the students to another expert, referring to the law and not being afraid of being subjected criminal sanction. At the same time, the students will not suffer, and the situation will be a win-win, as it has been well proven above.

It is necessary to emphasize that this is not about medical care denial if human life; such cases are unambiguously and clearly stated in the Federal law "About Bases of Protection of Public Health of the Russian Federation" as of 21.11.2011 and in the Criminal Code of the Russian Federation. There is a need to note that the health care denial can be considered as lawful only when it is issued properly in strict accordance with the current legislation. In other cases, medical assistance denial cannot be regarded as lawful (Ebrahim Abadi \& Namdar, 2016; The federal law as of 21.11.2011 N 323-FZ; 2017).

\section{Conclusions}

What can there be said in the conclusion? The legislation of the Russian Federation majorly regards the paramount importance of the students' rights, and the rights of the doctor however often fail to see the student as a full party of the health care needs. Therefore, as well as the students, in the framework which is strictly limited by the legislation, a medical worker has to have the right to refuse to work with the specific students for the objective or subjective reasons, as well as the students has the right to refuse receiving treatment from a specific doctor in the medical organization, except for the cases requiring emergency medical attention.

\section{Acknowledgments}

The work is performed according to the Russian Government Program of Competitive Growth of Kazan Federal University. 


\section{References}

Boroomand, Z., Momeni, M., \& Torkashvand, M. H. (2016). Evaluating the Possibility of Establishing Knowledge Management in State Welfare Organization of Iran. UCT Journal of Management and Accounting Studies, 4(2), 7-15.

Criminal Code of the Russian Federation Article 124. (2017). Failure to provide help to the students//ConsultantPlus [Electronic resource]. URL: http://www.consultant.ru/document /cons_doc_LAW_10699/278a7483be20f760f29fa44e5a34f7bae96c0c03/. [Reference date: On October 1, 2017].

Dale, W. (1977). Legislative Drafting: A New Approach: a Comparative Study of Methods in France, Germany, Sweden, and the United Kingdom. - London: Butterworths, - $341 \mathrm{p}$.

Davies, P. (2016). Rectification versus interpretation: the nature and scope of the equitable jurisdiction. - The Cambridge Law Journal, 75(1), 62-85.

Demieva, A. G., Arslanov, K. M. (2016). Legislation on Business: the International Experience and the Prospects of Development in Russia. The Turkish Online Journal of Design, Art, and Communication (TOJDAC). - November, Special Edition. - P.2474-2479.

Ebrahim Abadi, M., \& Namdar, Sh. (2016). Comparison between the legal nature of commercial factoring and similar legal institutions. UCT Journal of Social Sciences and Humanities Research, 4(2), 10-15.

Ethical Code of the Russian Doctor. (1994). MEDICINE AND LAW [Electronic resource]. URL: http://www.medpravo.ru/Ethics/EthCodRF.htm. [Reference date: On October 1, 2017].

Gutteridge, H. C. (1947). Comparative Law. An Introduction to the Comparative Method of Legal Study and Research. (Cambridge Studies in International and Comparative Law, Vol. I.) London: Cambridge University Press. The Cambridge Law Journal, 9(3), 386-387.

Marques, C. G., Manso, A., Ferreira, A. P., Morgado, F., \& Gaspar, M. (2017). Learning Information Systems: Designing Education Programs Using Letrinhas. Journal of Information Systems Engineering \& Management, 2(1), 6. https://doi.org/10.20897/jisem.201706

Medical care denial for a good reason, (2017). Medical website Surgeryzone [Electronic resource]. URL: http://surgeryzone.net/info/obshhemedicinskaya-informaciya/otkaz-bolnomu-v-medicinskoj-pomoshhi-pouvazhitelnoj-prichine.html. [Reference date: October of 1 2017].

Mental health: strengthening our response. (2018). [Электронный pecypc]. - URL: http://www.who.int/newsroom/fact-sheets/detail/mental-health-strengthening-our-response (дата обращения: 29.06.2018).

Olmos, R. A. V. (2007). Laws of Russia: experience, analysis, practice. Moscow.

Pakdel, M., \& Talebbeydokhti, A. (2018). The Effect of Adjustment Announcement of Predicted Profit on Price and Trading Volume of Listed Companies in Tehran Stock Exchange. Dutch Journal of Finance and Management, 2(1), 49. https://doi.org/10.29333/djfm/5825

Radhy, Z. H. (2019). Application of Multiply Regression Linear Model and New Technology Method in Estimating Learning and Education of Students. International Electronic Journal of Mathematics Education, 14(1), 87-90. https://doi.org/10.12973/iejme/3978

Russian Federation Constitution. (1993). The Russian newspaper, 25 December 1993 Enacted by national voting on December 12.

Siems, M., \& Mac Síthigh, D. (2012). Mapping legal research. The Cambridge Law Journal, 71(3), 651-676.

The federal law as of 21.11.2011 N 323-FZ (2017). About Bases of Protection of the Public Health in the Russian Federation" 29 September 2017. [Electronic resource]. URL: http://www.consultant.ru/document/cons_doc_LAW_121895/. [Reference date: On October 1, 2017]. 